\title{
Osady polodowcowe w żwirowni w Paplinie (Wysoczyzna Rawska) w świetle badań teksturalnych
}

\author{
The post-glacial deposits of gravel pit in Paplin (Rawa Upland) on the basis of textural \\ analyses
}

\author{
Anna Lejzerowicz ${ }^{1 *}$, Anna Wysocka² \\ ${ }^{1}$ Wydział Inżynierii Lądowej, Politechnika Warszawska, Warszawa; *a.lejzerowicz@il.pw.edu.pl \\ ${ }^{2}$ Wydział Geologii, Uniwersytet Warszawski, Warszawa
}

\begin{abstract}
Zarys treści: Teren badań znajduje się około $60 \mathrm{~km}$ na południowy zachód od Warszawy. Żwirownia w Paplinie zlokalizowana jest na Wysoczyźnie Rawskiej w strefie wysoczyzny polodowcowej zlodowacenia środkowopolskiego. Badaniom sedymentologicznym poddano osady polodowcowe odsłaniające się wzdłuż południowo-wschodniej ściany wyrobiska. Przeprowadzono analizy: uziarnienia, charakteru obtoczenia i zmatowienia powierzchni ziaren kwarcu frakcji 0,5-1,0 mm według Krumbeina (1941) w modyfikacji Goździka (1980) oraz Mycielskiej-Dowgiałło i Woronko (1998), a także analizę mineralno-petrograficzną frakcji 0,5-1,0 mm według Kenig (1999). Wskaźniki teksturalne, tj.: średnia średnica $\left(\mathrm{M}_{\mathrm{z}}\right)$, wysortowanie $\left(\sigma_{1}\right)$, skośność $\left(\mathrm{Sk}_{1}\right)$ oraz spłaszczenie $\left(\mathrm{K}_{\mathrm{G}}\right)$ obliczono metodą Folka i Warda $(1957)$ z wykorzystaniem programu Gradistat. Uzyskane wyniki pozwoliły na ilościową charakterystykę cech osadu. Zaobserwowano stosunkowo duże zróżnicowanie badanych osadów: od dominujących osadów drobnoziarnistych deponowanych w niskoenergetycznym środowisku, charakteryzujących się warstwowaniami przekątnymi i rynnowymi, do osadów gruboziarnistych deponowanych $\mathrm{w}$ środowisku intensywnego przepływu wód z topniejącego lądolodu. Większość osadów była transportowana w zawiesinie. Zaobserwowana została duża jednorodność osadów ze względu na charakter obtoczenia i zmatowienia powierzchni ziaren kwarcu oraz skład mineralno-petrograficzny.
\end{abstract}

Słowa kluczowe: analizy teksturalne, parametry uziarnienia, osady polodowcowe, Wysoczyzna Rawska

Abstract: The study area is located approximately $60 \mathrm{~km}$ south-west of Warsaw. Gravel pit in Paplin is located on the Rawa Upland in the glacial upland area of Middle-Poland glaciation. Post-glacial sediments exposing along the southeast wall of the excavation were subjected to sedimentological research. Following analyses were performed: the granulometric composition of deposits, the frosting and rounding analyses of sand quartz grains $(1.0-0.5 \mathrm{~mm})$ according to Krumbein (1941) and refined by Goździk (1980) and Mycielska-Dowgiałło and Woronko (1998) and mineralogical studies of sand fraction. Textual indicators i.e. mean grain size $\left(\mathrm{M}_{z}\right)$, standard deviation $\left(\sigma_{1}\right)$, skewness $\left(\mathrm{Sk}_{1}\right)$ and kurtosis $\left(\mathrm{K}_{\mathrm{G}}\right)$ were calculated according Folk and Ward formulas (1957) using the Gradistat program. The obtained results allowed the quantitative characteristics of the sediment features. Relatively high diversity of investigated sediments was observed: from dominating fine-grained sediments deposited in the low-energy environment, characterized by cross-stratification, to coarse-grained sediments deposited in the environment of intense flow of water from the melting glacier. Most of deposits was transported in suspension. High uniformity of deposits was observed regarding the rounding and frosting of quartz grains and mineral-petrographic composition.

Key words: textural analyses, grain-size parameters, post-glacial deposits, Rawa Upland

\section{Wprowadzenie}

Dzięki zastosowaniu analizy teksturalnej w badaniach osadów polodowcowych otrzymuje się szereg wskaźników i parametrów liczbowych, które pozwalają na ilościowe opisanie cech osadów oraz dynamiki środowiska (Mycielska-Dowgiałło 2001, 2007, Mycielska-Dowgiałło, Ludwikowska-Kędzia 2011). Użyte metody pozwalają prześledzić zmienność osadów w poszczególnych punktach badawczych. Wykorzystanie różnych metod analizy osadów (uziarnienia, charakteru powierzchni ziaren 
kwarcu, składu mineralogicznego) umożliwia otrzymanie wiarygodnych informacji o osadzie.

Celem badań jest poznanie cech teksturalnych osadów występujących w żwirowni w Paplinie na Wysoczyźnie Rawskiej, aby odtworzyć warunki depozycji osadów. Szczególną uwagę zwrócono na relacje pomiędzy najczęściej stosowanymi wskaźnikami uziarnienia (średnia średnica, wysortowanie, skośność, spłaszczenie), pozwalającymi na pośrednie wnioskowanie o dynamice środowiska.

\section{Położenie terenu badań}

Żwirownia w Paplinie (województwo lódzkie, powiat skierniewicki, gmina Kowiesy; ryc. 1a) znajduje się w strefie wysoczyzny lodowcowej z pokrywą sandrową nadbudowaną gliną zwałową i produktami jej wietrzenia. Obszar żwirowni położony jest w otulinie Bolimowskiego Parku Krajobrazowego (Janicki 2007, Glińska i in. 2010). Eksploatowano tutaj piaski do budowy szosy Warszawa-Katowice, obecnie materiał skalny pozyskiwany jest jedynie dla budownictwa lokalnego. Wydobycie kruszywa odsłoniło przekrój przez Wysoczyznę Rawską (ryc. 1c) i dało możliwość podziwiania różnorodności litologicznej osadów (ryc. 2), z których jest ona zbudowana (Glińska i in. 2006).

Miąższość osadów czwartorzędowych w rejonie żwirowni w Paplinie wynosi do $50 \mathrm{~m}$. Na tym obszarze występują dwa poziomy wodonośne. Pierwszy charakteryzuje się swobodnym zwierciadłem i znajduje się na głębokości 5,6-16,7 m. Drugi poziom występuje na głębokości około 30-35 m i jest izolowany od pierwszego poziomu wodonośnego ciągłym poziomem glin zwałowych zlodowacenia odry (Janicki 2007).
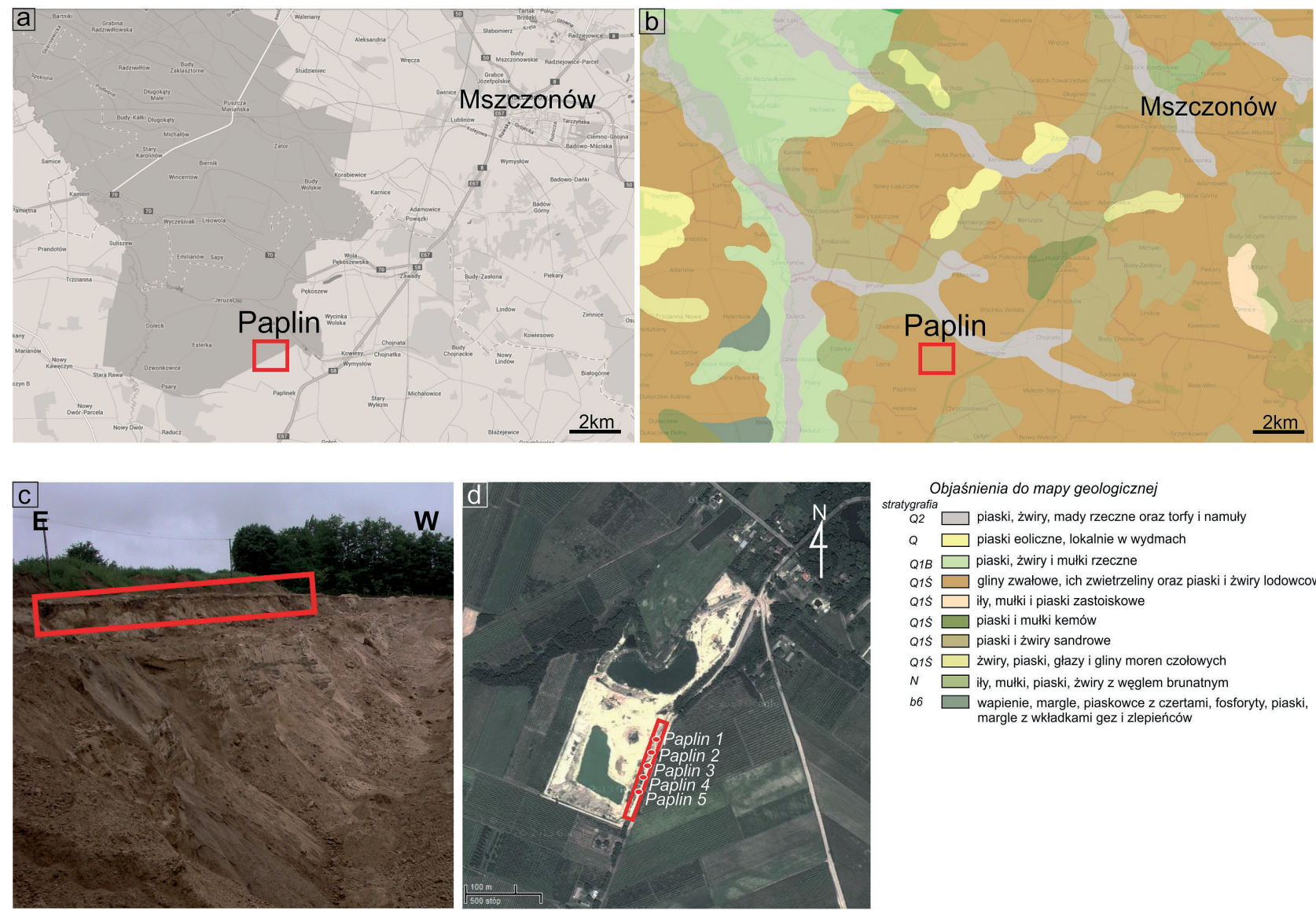

Objaśnienia do mapy geologicznej

Q2 $_{\text {atyrafia }} \square$ piaski, żwiry, mady rzeczne oraz torfy i namuły

Q $\square$ piaski eoliczne, lokalnie w wydmach

Q1B $\square$ piaski, żwiry i mukki rzeczne

Q1S gliny zwalowe, ich zwietrzeliny oraz piaski i żwiry lodowcowe Q1S $\square$ ily, mukki i piaski zastoiskowe

Q1S piaski i mułki kemów

Q1Ś $\square$ piaski i mułki kemów

Q1s $\square$ żwiry, piaski, głazy i gliny moren czołowych

N $\square$ ily, mułki, piaski, żwiry z wẹglem brunatnym

b6 $\square$ wapienie, margle, piaskowce $z$ czertami, fosforyty, piaski margle $z$ wkładkami gez i zlepieńców

Ryc. 1. Teren badań

a) lokalizacja terenu badań (czerwony kwadrat) na mapie topograficznej (www.maps.google.pl; zmienione), b) lokalizacja terenu badań (czerwony kwadrat) na mapie geologicznej (http://m.bazagis.pgi.gov.pl; zmienione) wraz z objaśnieniami, c) zdjęcie żwirowni z widokiem (czerwony prostokąt) na południowo-wschodnią ścianę wyrobiska (fot. A. Lejzerowicz, 2011), d) zdjęcie satelitarne rejonu żwirowni w Paplinie z zaznaczonym (czerwony prostokąt) obszarem badań oraz punktami badawczymi: Paplin 1, 2, 3, 4, 5 (www.maps. google.pl 2014; zmienione)

Fig. 1. Study area

a) location of study area (red square) on the background of topographic map (www.maps.google.pl; adapted), b) location of study area (red square) on the background of geological map (http://m.bazagis.pgi.gov.pl; adapted) with legend, c) photo of gravel pit with a view (red rectangle) on south-eastern wall of an excavation (photo A. Lejzerowicz, 2011), d) satellite image of Paplin gravel pit area with marked (red rectangle) study area and research points: Paplin 1, 2, 3, 4, 5 (www.maps.google.pl 2014; adapted) 


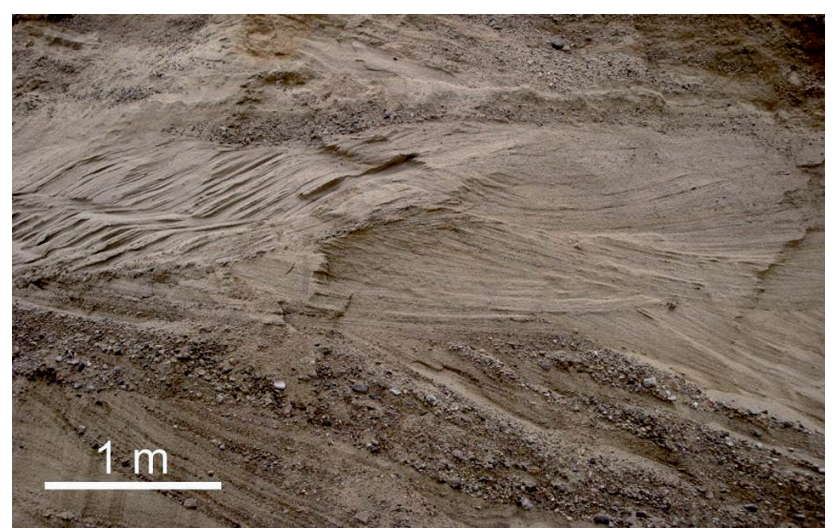

Ryc. 2. Widok fragmentu południowo-wschodniej ściany żwirowni w Paplinie (fot. A. Lejzerowicz, 2011)

Fig. 2. A view of the fragment of the south-eastern wall of the gravel pit in Paplin (photo A. Lejzerowicz, 2011)
W ścianach wyrobiska odsłaniają się osady zlodowacenia warty reprezentowane przez gliny zwałowe, piaski, żwiry (ryc. 2) oraz mułkowate osady zastoiskowe. Wyżej zalegają piaski i żwiry wodnolodowcowe, które charakteryzują się: różnorodnością uziarnienia, zmiennym wysortowaniem materiału, urozmaiconym składem litologicznym oraz przekątnymi czy rynnowymi warstwowaniami. W najwyższej części profilu występuje warstwa osadów mulkowych reprezentująca osady jeziora zastoiskowego (Markowiak 2010).

\section{Metody badań}

Wytypowano 5 punktów badawczych (ryc. 1c, d) wzdłuż południowo-wschodniej ściany wyrobiska

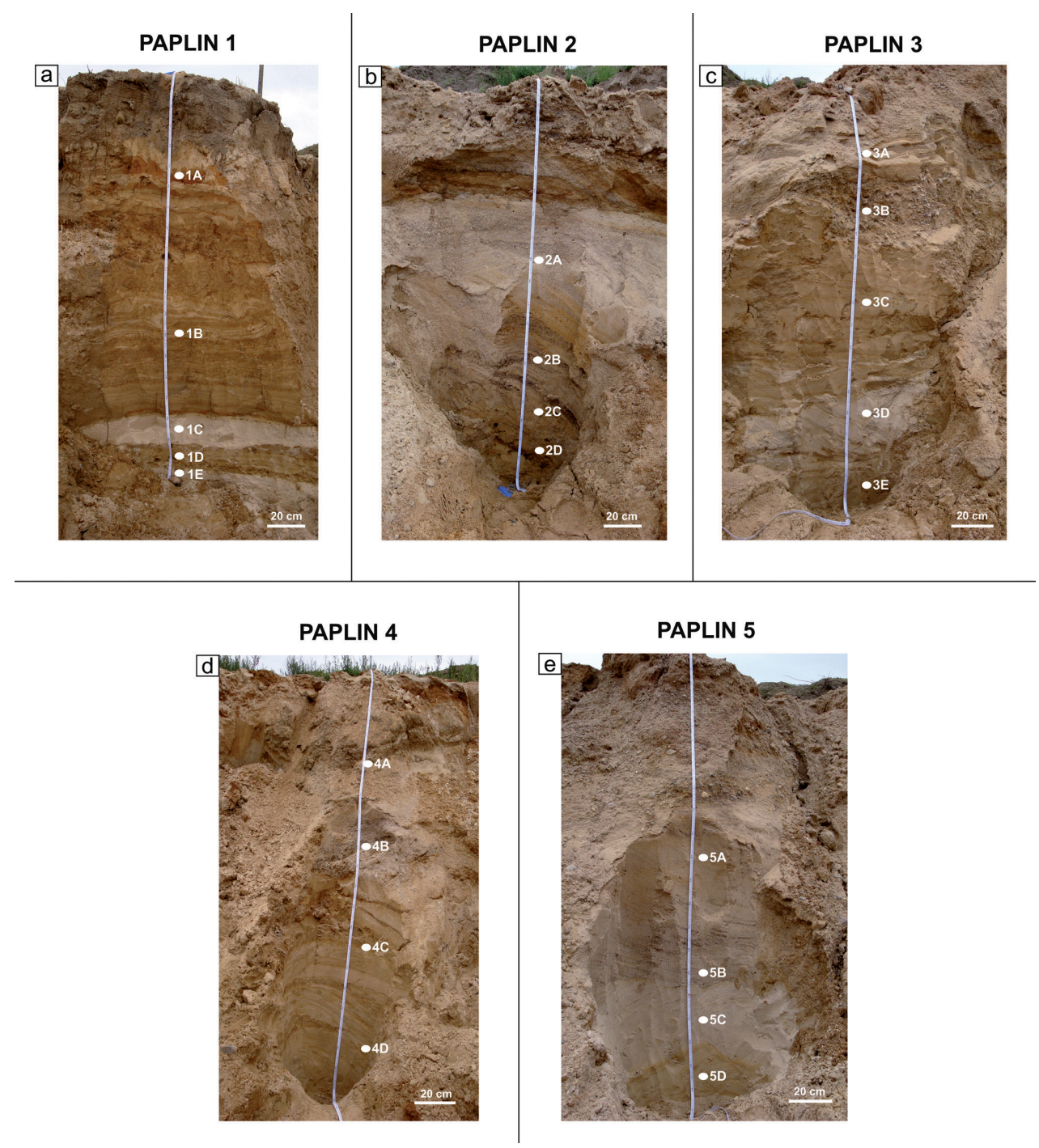

Ryc. 3. Zdjęcia poszczególnych punktów badawczych (fot. A. Lejzerowicz, 2011) z zaznaczonymi miejscami poboru próbek do badań laboratoryjnych

a) profil Paplin 1, b) profil Paplin 2, c) profil Paplin 3, d) profil Paplin 4, e) profil Paplin 5

Fig. 3. Photos of individual research points (photo A. Lejzerowicz, 2011) with marked locations of sampling for laboratory tests

a) profile Paplin 1, b) profile Paplin 2, c) profile Paplin 3, d) profile Paplin 4, e) profile Paplin 5 
i pobrano z nich próbki (ryc. 3) do badań laboratoryjnych (Paplin 1, 2, 3, 4, 5). Przeprowadzono analizy: uziarnienia, charakteru obtoczenia i zmatowienia powierzchni ziaren kwarcu frakcji $0,5-1,0 \mathrm{~mm}$ według Krumbeina (1941) w modyfikacji Goździka (1980) oraz Mycielskiej-Dowgiałło i Woronko (1998), a także analizę mineralogiczno-petrograficzną frakcji 0,5-1,0 mm według Kenig (1999).

Ze względu na zły stan odsłonięcia brak jest możliwości pełnej korelacji poszczególnych profili. W każdym z punktów badawczych (ryc. 3) od 35 do $120 \mathrm{~cm}$ górnej części profilu to skarpa osuwiskowa lub osady antropogeniczne.

Analizy uziarnienia pobranych $\mathrm{w}$ terenie próbek wykonano metodą sitową, wykorzystując zestaw sit o średnicach oczek: $4 \mathrm{~mm}, 2 \mathrm{~mm}, 1 \mathrm{~mm}, 0,5 \mathrm{~mm}$, $0,25 \mathrm{~mm}$ oraz $0,1 \mathrm{~mm}$. Poszczególnym sitom przypisano następujące wartości w skali phi $[\varphi]$ (odpowiednio): $-2 \varphi,-1 \varphi, 0 \varphi, 1 \varphi, 2 \varphi$ oraz $3 \varphi$, gdyż dalsze obliczenia (wyznaczenie statystycznych parametrów uziarnienia) wymagały wykorzystania tej jednostki.

Parametry uziarnienia: średnią średnicę $\left(\mathrm{M}_{\mathrm{z}}\right)$, wysortowanie $\left(\sigma_{1}\right)$, skośność $\left(\mathrm{Sk}_{1}\right)$ oraz spłaszczenie $\left(\mathrm{K}_{\mathrm{G}}\right)$ obliczono metodą Folka i Warda (1957), używając programu Gradistat. Przy ich interpretacji uwzględniono uwagi Mycielskiej-Dowgiałło $(1995,2007)$.

Badania zmatowienia i obtoczenia ziaren kwarcu wykonane zostały przez dr. inż. Bogusława Marcinkowskiego z PIG-PIB. Analizę ziaren kwarcu w liczbie nieznacznie poniżej 200 sztuk (200 sztuk minus inne, poza jasnym kwarcem, minerały wchodzące w skład badanych próbek) wykonano za pomocą mikroskopu stereoskopowego (lupa binokularna), wykorzystując powiększenie ziaren $16-25$ razy. Podobnego powiększenia użyto dla określenia składu mineralno-petrograficznego badanych próbek. Dla ustalenia stopnia zmatowienia i obtoczenia posłużono się metodą Krumbeina (1941), udoskonalaną następnie przez Goździka (1980, 1995) oraz Mycielską-Dowgiałło i Woronko (1998).

Badania mineralogiczno-petrograficzne wykonano mikroskopem stereoskopowym, wykorzystując światło odbite. Badania zostały przeprowadzone dla klas wielkości ziaren 0,5-1,0 mm. Z analizowanych próbek wybierano losowo 200 ziaren, wśród których wyróżniono: kwarc, granit czerwony, granit szary, wapień, kwarcyt, tlenki żelaza oraz inne minerały (niezaklasyfikowane do żadnej z grup).

\section{Wyniki}

\section{Analizy uziarnienia}

Wykonane analizy granulometryczne pozwoliły na porównanie klas wielkości ziaren (frakcji) w osadach w poszczególnych punktach badawczych. Miejsca pobrania próbek do badań laboratoryjnych zostały zaznaczone na rycinie 3.

Paplin 1

W osadach $z$ tego profilu (ryc. 1, 3a) dominuje frakcja 0,25-0,1 mm (próbki 1A, 1C, 1E) oraz frakcja <0,1 $\mathrm{mm}$ (próbki 1B, 1D). W próbce 1E (ryc. 4) znaczący jest również udział frakcji $>0,25 \mathrm{~mm}$, a w próbce 1D pojawia się frakcja żwirowa $(>2 \mathrm{~mm})$. Osady występujące $\mathrm{w}$ tym profilu można więc zaklasyfikować jako piaski drobnoziarniste (1A, 1C, 1D, 1E) oraz w jednym przypadku (próbka $1 \mathrm{~B}$ ) jako mułki piaszczyste. Wykres kołowy przedstawiający średnie
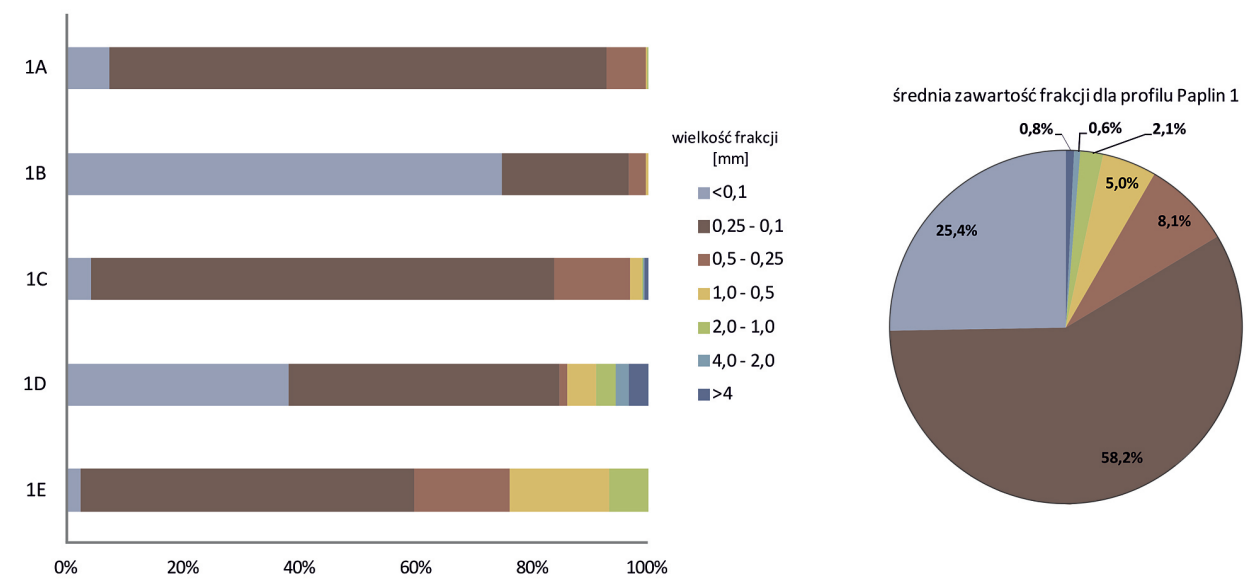

Ryc. 4. Udział poszczególnych frakcji [\%] w osadach żwirowni w Paplinie dla profilu Paplin 1

Przedziały frakcji i typy osadów: $>4 \mathrm{~mm}$ - żwir średnioziarnisty i frakcje większe, 4,0-2,0 mm - żwir drobnoziarnisty, 2,0-1,0 mm piasek bardzo gruboziarnisty, 1,0-0,5 mm - piasek gruboziarnisty, 0,5-0,25 mm - piasek średnioziarnisty, 0,25-0,1 mm - piasek drobnoziarnisty, <0,1 mm - piasek bardzo drobnoziarnisty i frakcje drobniejsze

Fig. 4. The share of individual fractions [\%] in sediments in Paplin gravel pit for the profile Paplin 1

Ranges of factions and types of deposits: $>4 \mathrm{~mm}$ - medium gravel and larger fractions, $4.0-2.0 \mathrm{~mm}-$ fine gravel, $2.0-1.0 \mathrm{~mm}-$ very coarse sand, $1.0-0,5 \mathrm{~mm}$ - coarse sand, $0.5-0.25 \mathrm{~mm}$ - medium sand, $0.25-0.1 \mathrm{~mm}$ - fine sand, $<0.1 \mathrm{~mm}$ - very fine sand and finer fractions 

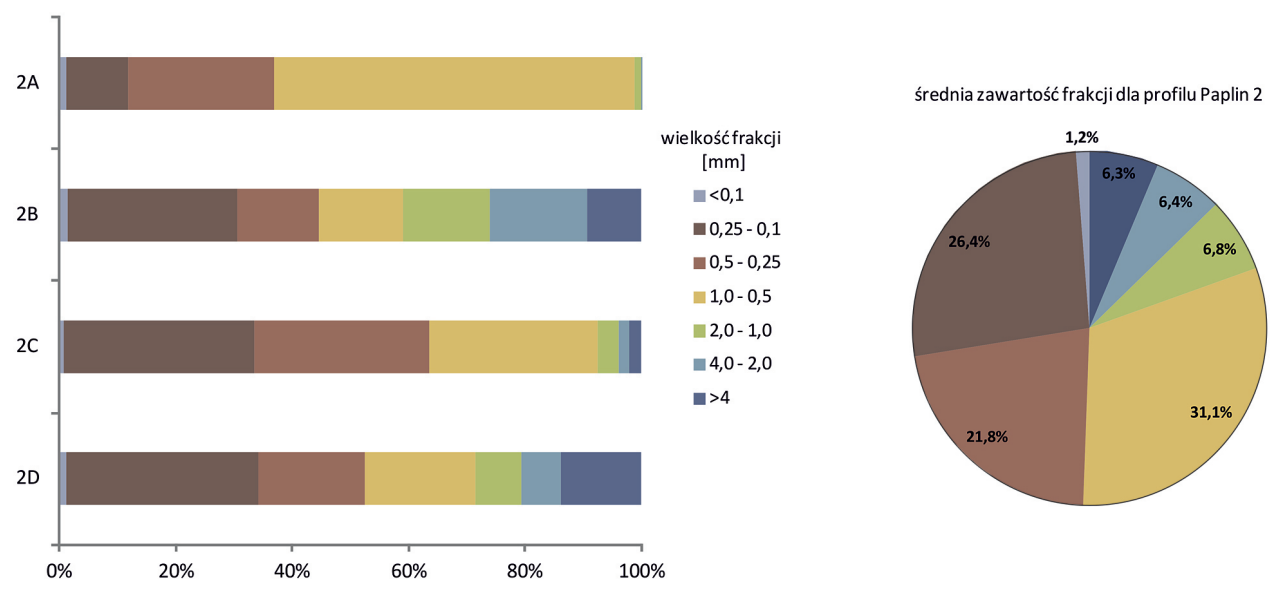

Ryc. 5. Udział poszczególnych frakcji [\%] w osadach żwirowni w Paplinie dla profilu Paplin 2

Przedziały frakcji i typy osadów jak w opisie ryc. 4

Fig. 5. The share of individual fractions [\%] in sediments in Paplin gravel pit for the profile Paplin 2 Ranges of factions and types of deposits as in the description of Fig. 4

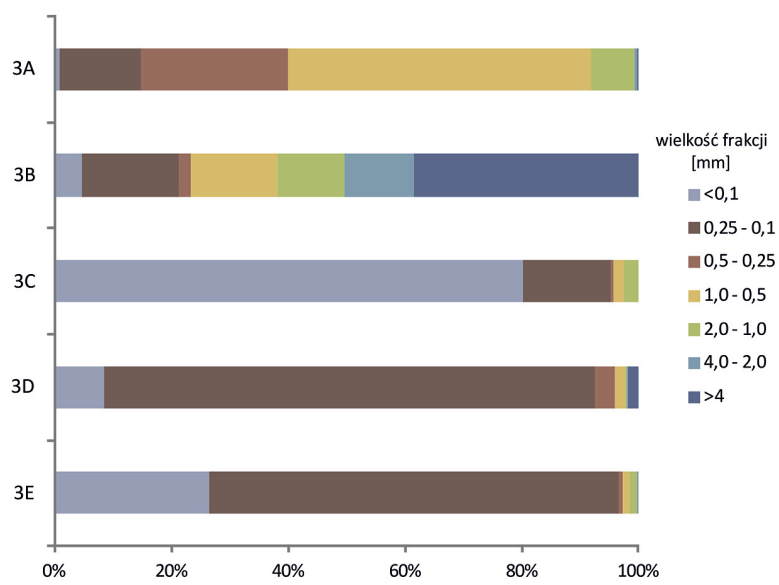

średnia zawartość frakcji dla profilu Paplin 3

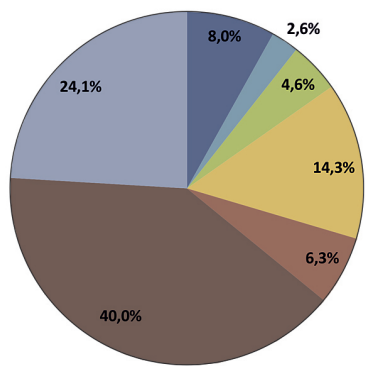

Ryc. 6. Udział poszczególnych frakcji [\%] w osadach żwirowni w Paplinie dla profilu Paplin 3 Przedziały frakcji i typy osadów jak w opisie ryc. 4

Fig. 6. The share of individual fractions [\%] in sediments in Paplin gravel pit for the profile Paplin 3 Ranges of factions and types of deposits as in the description of Fig. 4

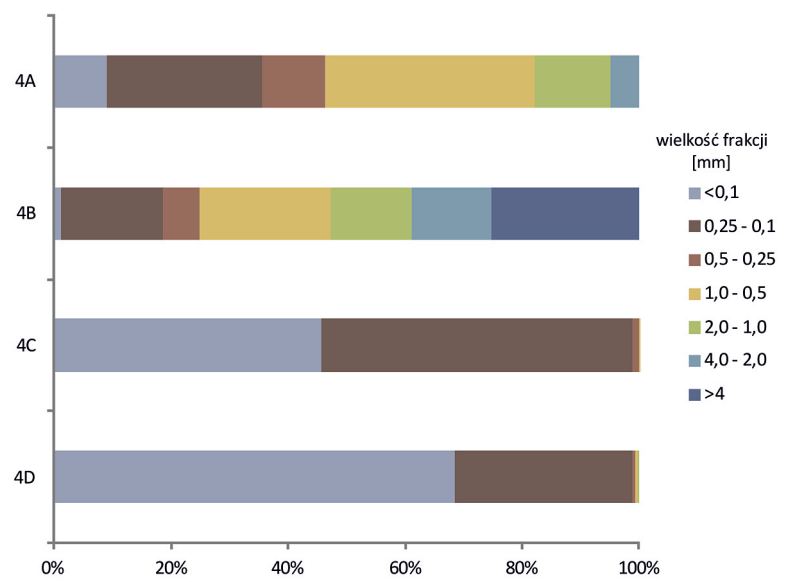

Średnia zawartość frakcji dla profilu Paplin 4

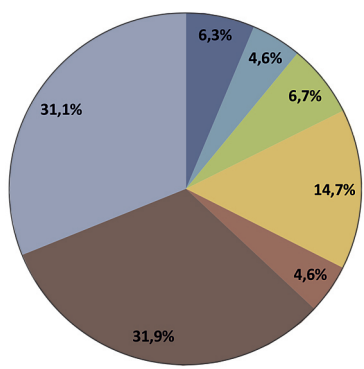

Ryc. 7. Udział poszczególnych frakcji [\%] w osadach żwirowni w Paplinie dla profilu Paplin 4 Przedziały frakcji i typy osadów jak w opisie ryc. 4

Fig. 7. The share of individual fractions [\%] in sediments in Paplin gravel pit for the profile Paplin 4 Ranges of factions and types of deposits as in the description of Fig. 4 
zawartości frakcji dla profilu Paplin 1 obrazuje dominację frakcji 0,25-0,1 mm (58,2\%), czyli piasków drobnoziarnistych.

\section{Paplin 2}

Profil Paplin 2 (ryc. 1, 3b) charakteryzuje się dominacją frakcji 1,0-0,5 mm, co zauważalne jest zwłaszcza $\mathrm{W}$ punkcie $2 \mathrm{~A}$ (ryc. 5). W kolejnych punktach (2B, 2C, 2D) dominują frakcje $\mathrm{w}$ przedziałach $0,25-0,1$, $0,5-0,25$ oraz $1,0-0,5 \mathrm{~mm}$. Obecność frakcji żwirowej (4-2 $\mathrm{mm}$ oraz $>4 \mathrm{~mm}$ ) wyraźnie zaznacza się $\mathrm{w}$ punkcie $2 \mathrm{~B}$ oraz 2D. Charakterystyczną cechą dla tego profilu jest obecność $\mathrm{w}$ zbliżonych proporcjach (od 20 do $30 \%$ ) frakcji $\mathrm{w}$ przedziale $0,25-0,1 \mathrm{~mm}$ (piasek drobnoziarnisty), 0,5-0,25 mm (piasek średnioziarnisty) oraz 1,0-0,5 mm (piasek gruboziarnisty). Dominuje frakcja $1,0-0,5 \mathrm{~mm}(31,1 \%)$, dlatego też osady w profilu Paplin 2 można zaklasyfikować jako piaski gruboziarniste.

\section{Paplin 3}

Osady profilu Paplin 3 (ryc. 1, 3c), ze względu na uziarnienie, można podzielić na dwie grupy (ryc. 6): osady $z$ dominującymi drobniejszymi frakcjami $<0,1 \mathrm{~mm}$ oraz $0,25-0,1 \mathrm{~mm}$ (próbki 3C, 3D, 3E) i osady, w których przeważają frakcje grubsze 1,0$0,5 \mathrm{~mm}$ (3A) oraz $>4 \mathrm{~mm}$ (3B). Osady drobniejsze (próbki 3C, 3D, 3E) można zaklasyfikować jako piaski drobnoziarniste, natomiast osady o większych średnicach jako piaski gruboziarniste (3A, 3B). Profil Paplin 3 charakteryzuje się wyraźną dwudzielnością: dolna część profilu (próbki 3C, 3D, 3E) cechuje się obecnością osadów drobnoziarnistych, zaś górna część profilu (do głębokości ok. $80 \mathrm{~cm}$; próbki 3A, 3B) reprezentowana jest przez osady o większych średnicach. Diagram kołowy (ryc. 6) średniej zawartości [\%] poszczególnych frakcji dla całego profilu Paplin 3 obrazuje dominację piasku drobnoziarnistego (40\%), frakcji bardzo drobnoziarnistej $<0,1 \mathrm{~mm}$ $(24,1 \%)$. Wyraźnie zaznacza się też obecność frakcji żwirowej $>4 \mathrm{~mm}(8 \%)$.

\section{Paplin 4}

W osadach $z$ tego profilu (ryc. 1, 3d) można również zaobserwować wyraźny podział ze względu na uziarnienie na dwie grupy osadów (ryc. 7): dolna część profilu (od głębokości ok. $170 \mathrm{~cm}$; próbki 4C, 4D) z przeważającą obecnością osadów drobnoziarnistych frakcji $<0,1 \mathrm{~mm}$ i $0,25-0,1 \mathrm{~mm}$ oraz górna część profilu (próbki 4A, 4B), gdzie przeważają osady gruboziarniste frakcji $>0,5 \mathrm{~mm}$. Osady z punktów 4A oraz 4B można określić jako piaski żwirowe lub żwiry piaszczyste (zwłaszcza w przypadku próbki 4B), natomiast osady z punktów 4C oraz 4D można zaklasyfikować jako piaski mułkowe/mułki piaszczyste. Na diagramie kołowym (ryc. 7) ze średnią zawartością frakcji dla całego profilu, widać dominację frakcji 0,25-0,1 mm (31,9\%) oraz <0,1 mm (31,1\%). Wyraźnie zaznacza się również obecność piasków gruboziarnistych $1,0-0,5 \mathrm{~mm}(14,7 \%)$ oraz frakcji żwirowej $>4 \mathrm{~mm}(6,3 \%)$.

\section{Paplin 5}

Profil Paplin 5 (ryc. 1, 3e) jest kolejnym profilem, w którym można zaobserwować podział ze względu na uziarnienie na dwie grupy osadów i dwudzielność profilu (ryc. 8): niższa część profilu (próbki 5C, 5D) $z$ osadami drobnoziarnistymi frakcji $<0,25 \mathrm{~mm}$ oraz wyższa część profilu (do głębokości około $190 \mathrm{~cm}$; próbki $5 \mathrm{~A}, 5 \mathrm{~B}) \mathrm{z}$ osadami gruboziarnistymi frakcji $>0,25 \mathrm{~mm}$. Osady z punktów 5A i 5B można zaklasyfikować jako drobno- i średnioziarniste piaski $z$ niewielką domieszką frakcji żwirowej, natomiast osady z punktów 5C oraz 5D - jako drobnoziarniste piaski/gruboziarniste mułki. Analizując diagram kołowy (ryc. 8) ze średnią zawartością frakcji dla całego profilu, zauważyć można dominację $(48,3 \%)$ frakcji 0,25-0,1 mm. Wyraźnie zaznacza się również obecność frakcji najdrobniejszych $<0,1 \mathrm{~mm}(23,1 \%)$.

\section{Parametry uziarnienia}

Parametry uziarnienia: średnia średnica, wysortowanie, skośność oraz spłaszczenie, zostały obliczone (przy użyciu programu Gradistat) i opisane metodą zaproponowaną przez Folka i Warda (1957). Wyniki zaprezentowano w tabeli 1 oraz na rycinie 9 (średnia średnica i wysortowanie).

\section{Średnia średnica - mediana $\left(\mathrm{M}_{\mathrm{z}}\right)$}

Przyjmuje się, że wskaźnik charakteryzujący przeciętną wielkość ziaren w osadzie pozwala na pośrednią interpretację dynamiki środowiska sedymentacyjnego (Racinowski i in. 2001). Interpretacja rodzaju transportu oparta została na klasyfikacji Allena i in. (1972), który zaproponował podział frakcyjny osadów na cztery grupy podlegające depozycji z czterech rodzajów ruchu: (1) trakcyjnego - ziarna o średnicy w zakresie do 0,6 phi, (2) saltacyjnego 0,6-2,0 phi, (3) zawiesiny gradacyjnej $-2-3$ phi, (4) zawiesiny jednorodnej - ziarna drobniejsze od 3 phi.

W profilu Paplin 1 (tab. 1) wartość średniej średnicy ziaren waha się od 1,93 do 4,88 $\varphi$ (średnio 3,14 $\varphi)$. Średnia wartość mediany wskazuje na dominację piasków drobnoziarnistych, co zauważalne jest również w całym profilu Paplin 1 (ryc. 9a). Średnia wartość tego parametru oznacza, że osady były transportowane w zawiesinie (por. Allen i in. 1972). Wartości $\mathrm{M}_{\mathrm{z}}$ (tab. 1) świadczą o tym, że osady z próbek $1 \mathrm{~A}$, $1 \mathrm{~B}, 1 \mathrm{C}$ oraz $1 \mathrm{D}$ były transportowane $\mathrm{w}$ zawiesinie, natomiast osady z próbki 1E poprzez saltację.

W profilu Paplin 2 (tab. 1) wartość średniej średnicy ziarna waha się od 0,56 do 1,49 $\varphi$ (średnio 0,93 $\varphi$ ). Średnia wartość mediany wskazuje na dominację pia- 

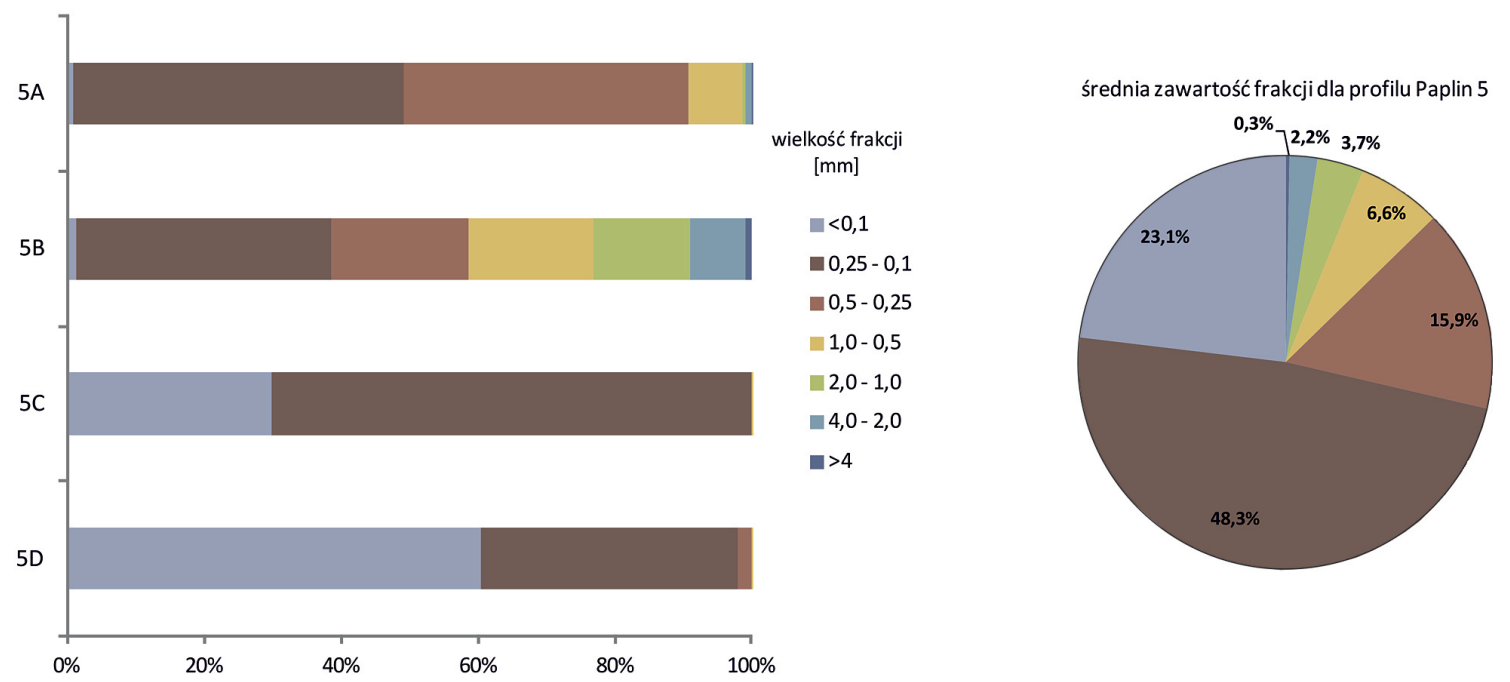

Ryc. 8. Udział poszczególnych frakcji [\%] w osadach żwirowni w Paplinie dla profilu Paplin 5 Przedziały frakcji i typy osadów jak w opisie ryc. 4

Fig. 8. The share of individual fractions [\%] in sediments in Paplin gravel pit for the profile Paplin 5 Ranges of factions and types of deposits as in the description of Fig. 4

sków gruboziarnistych, co zauważalne jest również w całym profilu Paplin 2 (ryc. 9a). Średnie wartości tego parametru oznaczają, że osady były transportowane poprzez saltację (próbki 2A, 2C, 2D). Tylko dla jednej próbki (2B) wartości $\mathrm{M}_{z}$ (tab. 1) wskazują na transport poprzez trakcję (por. Allen i in. 1972).

W profilu Paplin 3 (tab. 1) wartość średniej średnicy ziarna waha się od 0,18 do 5,04 $\varphi$ (średnio 2,46 $\varphi)$. Średnia wartość mediany wskazuje na dominację piasków drobnoziarnistych, jednak wartości te znacznie różnią się $\mathrm{W}$ poszczególnych próbkach. Patrząc od dołu profilu (ryc. 9a), można zauważyć stopniowe przejście od piasków bardzo drobnoziarnistych (próbka 3E) i piasków drobnoziarnistych (próbka 3D), poprzez piaski średnio- i drobnoziarniste do mułków gruboziarnistych (próbka 3C) i piasków gruboziarnistych (próbki 3A, 3B). Mediana wynosi 2,67, 3,43 i 5,04 $\varphi$ odpowiednio dla próbek 3D, 3E i 3C, co oznacza, że osady te były transportowane w zawiesinie (por. Allen i in. 1972). Osady $z$ próbki $3 \mathrm{D}\left(\mathrm{M}_{\mathrm{z}}=2,67 \varphi\right)$ mogły być transportowane saltacyjnie, zaś z próbki $3 \mathrm{~B}\left(\mathrm{M}_{z}=0,18 \varphi\right)$ najprawdopodobniej trakcyjnie (por. Allen i in. 1972).

W profilu Paplin 4 (tab. 1, ryc. 9a) wartość średniej średnicy ziarna waha się od 0,25 do 4,71 $\varphi$ (średnio $2,55 \varphi$ ). Średnia wartość mediany wskazuje na dominację piasków drobnoziarnistych, jednak, podobnie jak w przypadku profilu Paplin 3, wartości te znacznie różnią się w poszczególnych próbkach. Patrząc od dołu profilu (ryc. 9a), można zauważyć, że profil rozpoczyna się mułkami bardzo gruboziarnistymi (próbka 4D), a następnie można zaobserwować stopniowe przejście od piasków średnioziarnistych, poprzez piaski drobno- i bardzo drobnoziarniste (próbka 4C) do piasków gruboziarnistych (próbka 4B) oraz piasków średnioziarni- stych (próbka 4A). Mediana wynosi 3,98 i 4,71 $\varphi$ odpowiednio dla próbek 4C i 4D, co wskazuje, że osady te były transportowane w zawiesinie (por. Allen $\mathrm{i}$ in. 1972). Osady $\mathrm{z}$ próbki $4 \mathrm{~A}\left(\mathrm{M}_{z}=1,24 \varphi\right)$ mogły być transportowane saltacyjnie, natomiast $z$ próbki $4 \mathrm{~B}\left(\mathrm{M}_{\mathrm{z}}=0,25 \varphi\right)$ najprawdopodobniej trakcyjnie (por. Allen i in. 1972).

W profilu Paplin 5 (tab. 1, ryc. 9a) wartość średniej średnicy ziarna waha się od 1,24 do 4,46 $\varphi$ (średnio $2,82 \varphi)$. Średnia wartość mediany wskazuje na dominację piasków drobnoziarnistych. Patrząc od dołu profilu (ryc. 9a) można zauważyć, że rozpoczyna się on mułkami bardzo gruboziarnistymi (próbka 5D), a potem przechodzi poprzez piaski drobno- i bardzo drobnoziarniste (próbka 5C) do piasków średnioziarnistych (próbka 5B) i piasków drobnoziarnistych (próbka 5A). Wartości mediany (tab. 1) wskazują, że osady były transportowane $\mathrm{w}$ zawiesinie (por. Allen $\mathrm{i}$ in. 1972) w przypadku próbek 5A, 5C i 5D lub poprzez saltację $\left(M_{z}=1,24 \varphi\right) \mathrm{w}$ przypadku próbki 5B.

\section{Wysortowanie $\left(\sigma_{1}\right)$}

Wartość tego wskaźnika identyfikowana jest z liczbowym wyrażeniem wysortowania osadu - im lepsze wysortowanie, tym mniejsze zróżnicowanie energetyczne środowiska (Folk, Ward 1957).

Profil Paplin 1 (ryc. 1, 3a) charakteryzuje się wartościami wysortowania (tab. 1, ryc. 9b) w przedziale od 0,61 do 2,32 (średnio 1,34), co wskazuje na umiarkowane, słabe oraz bardzo słabe wysortowanie, które mogło być spowodowane częściowym rozmywaniem osadu i jego redepozycją (por. Racinowski i in. 2001).

Profil Paplin 2 (ryc. 1, 3b) charakteryzuje się wartościami wysortowania (tab. 1, ryc. 9b) w przedziale od 0,82 do 1,71 (średnio 1,35), co oznacza słabe wysortowanie osadu i zmienną dynamikę środowiska. 
Tabela 1. Wskaźniki uziarnienia dla profilu Paplin 1 (1A-E), Paplin 2 (2A-D), Paplin 3 (3A-E), Paplin 4 (4A-D) and Paplin 5 (5A-D)

Table 1. Grain-size parameters for profile Paplin 1 (1A-E), Paplin 2 (2A-D), Paplin 3 (3A-E), Paplin 4 (4A-D) and Paplin $5(5 \mathrm{~A}-\mathrm{D})$

\begin{tabular}{|c|c|c|c|c|c|c|c|c|c|}
\hline \multirow{2}{*}{$\begin{array}{l}\vec{c} \\
\stackrel{0}{0}\end{array}$} & \multirow{2}{*}{$\begin{array}{l}\text { Numer } \\
\text { próbki }\end{array}$} & \multicolumn{2}{|c|}{$\begin{array}{c}\text { Średnia średnica } \\
\mathrm{M}_{\mathrm{z}} \\
\end{array}$} & \multicolumn{2}{|r|}{$\begin{array}{c}\text { Wysortowanie } \\
\sigma_{1} \\
\end{array}$} & \multicolumn{2}{|r|}{$\begin{array}{l}\text { Skośność } \\
\mathrm{Sk}_{1} \\
\end{array}$} & \multicolumn{2}{|r|}{$\begin{array}{c}\text { Spłaszczenie } \\
\mathrm{K}_{\mathrm{G}} \\
\end{array}$} \\
\hline & & {$[\varphi]$} & typ osadu & {$[-]$} & typ wysortowania & {$[-]$} & typ rozkładu & {$[-]$} & typ rozkładu \\
\hline \multirow{5}{*}{$\frac{\vec{\Xi}}{\vec{\Xi}}$} & $1 \mathrm{~A}$ & 2,66 & $\begin{array}{l}\text { drobnoziarnisty } \\
\text { piasek }\end{array}$ & 0,73 & umiarkowane & 0,19 & $\begin{array}{l}\text { dodatnio } \\
\text { skośny }\end{array}$ & 1,65 & $\begin{array}{l}\text { bardzo } \\
\text { leptokurtyczny }\end{array}$ \\
\hline & $1 \mathrm{~B}$ & 4,88 & $\begin{array}{l}\text { bardzo gruboziarnisty } \\
\text { mułek }\end{array}$ & 1,91 & słabe & 0,01 & symetryczny & 0,73 & platykurtyczny \\
\hline & $1 \mathrm{C}$ & 2,56 & $\begin{array}{l}\text { drobnoziarnisty } \\
\text { piasek }\end{array}$ & 0,61 & umiarkowane & $-0,16$ & ujemnie skośny & 1,07 & mezokurtyczny \\
\hline & $1 \mathrm{D}$ & 3,68 & $\begin{array}{l}\text { bardzo } \\
\text { drobnoziarnisty } \\
\text { piasek }\end{array}$ & 2,32 & bardzo słabe & 0,27 & $\begin{array}{l}\text { dodatnio } \\
\text { skośny }\end{array}$ & 1,33 & leptokurtyczny \\
\hline & $1 \mathrm{E}$ & 1,93 & $\begin{array}{l}\text { średnioziarnisty } \\
\text { piasek }\end{array}$ & 1,15 & słabe & $-0,39$ & $\begin{array}{l}\text { bardzo ujemnie } \\
\text { skośny }\end{array}$ & 0,83 & platykurtyczny \\
\hline \multirow{4}{*}{ 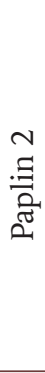 } & $2 \mathrm{~A}$ & 0,96 & gruboziarnisty piasek & 0,82 & umiarkowane & 0,40 & $\begin{array}{l}\text { bardzo } \\
\text { dodatnio } \\
\text { skośny }\end{array}$ & 1,05 & mezokurtyczny \\
\hline & $2 \mathrm{~B}$ & 0,56 & gruboziarnisty piasek & 1,71 & słabe & 0,08 & symetryczny & 0,52 & $\begin{array}{l}\text { bardzo } \\
\text { platykurtyczny }\end{array}$ \\
\hline & $2 \mathrm{C}$ & 1,49 & $\begin{array}{l}\text { średnioziarnisty } \\
\text { piasek }\end{array}$ & 1,19 & słabe & $-0,04$ & symetryczny & 0,91 & mezokurtyczny \\
\hline & $2 \mathrm{D}$ & 0,73 & gruboziarnisty piasek & 1,69 & słabe & $-0,12$ & ujemnie skośny & 0,57 & $\begin{array}{l}\text { bardzo } \\
\text { platykurtyczny }\end{array}$ \\
\hline \multirow{5}{*}{$\frac{n}{\Xi}$} & $3 \mathrm{~A}$ & 0,97 & gruboziarnisty piasek & 0,96 & umiarkowane & 0,27 & $\begin{array}{l}\text { dodatnio } \\
\text { skośny }\end{array}$ & 1,08 & mezokurtyczny \\
\hline & 3B & 0,18 & gruboziarnisty piasek & 1,35 & słabe & 1,28 & $\begin{array}{l}\text { bardzo } \\
\text { dodatnio } \\
\text { skośny }\end{array}$ & 0,66 & $\begin{array}{l}\text { bardzo } \\
\text { platykurtyczny }\end{array}$ \\
\hline & $3 \mathrm{C}$ & 5,04 & gruboziarnisty mułek & 1,88 & słabe & $-0,05$ & symetryczny & 0,80 & platykurtyczny \\
\hline & $3 \mathrm{D}$ & 2,67 & $\begin{array}{l}\text { drobnoziarnisty } \\
\text { piasek }\end{array}$ & 0,86 & umiarkowane & 0,15 & $\begin{array}{l}\text { dodatnio } \\
\text { skośny }\end{array}$ & 2,06 & $\begin{array}{l}\text { bardzo } \\
\text { leptokurtyczny }\end{array}$ \\
\hline & $3 \mathrm{E}$ & 3,43 & $\begin{array}{l}\text { bardzo } \\
\text { drobnoziarnisty } \\
\text { piasek }\end{array}$ & 1,50 & słabe & 0,62 & $\begin{array}{l}\text { bardzo } \\
\text { dodatnio } \\
\text { skośny }\end{array}$ & 1,78 & $\begin{array}{l}\text { bardzo } \\
\text { leptokurtyczny }\end{array}$ \\
\hline \multirow{4}{*}{$\frac{\pi}{\square}$} & $4 \mathrm{~A}$ & 1,24 & $\begin{array}{l}\text { średnioziarnisty } \\
\text { piasek }\end{array}$ & 1,75 & słabe & 0,37 & $\begin{array}{l}\text { bardzo } \\
\text { dodatnio } \\
\text { skośny }\end{array}$ & 1,13 & leptokurtyczny \\
\hline & $4 \mathrm{~B}$ & 0,25 & gruboziarnisty piasek & 1,39 & słabe & 0,63 & $\begin{array}{l}\text { bardzo } \\
\text { dodatnio } \\
\text { skośny }\end{array}$ & 0,47 & $\begin{array}{l}\text { bardzo } \\
\text { platykurtyczny }\end{array}$ \\
\hline & $4 \mathrm{C}$ & 3,98 & $\begin{array}{l}\text { bardzo } \\
\text { drobnoziarnisty } \\
\text { piasek }\end{array}$ & 1,81 & słabe & 0,58 & $\begin{array}{l}\text { bardzo } \\
\text { dodatnio } \\
\text { skośny }\end{array}$ & 0,78 & platykurtyczny \\
\hline & $4 \mathrm{D}$ & 4,71 & $\begin{array}{l}\text { bardzo gruboziarnisty } \\
\text { mułek }\end{array}$ & 1,90 & słabe & 0,11 & $\begin{array}{l}\text { dodatnio } \\
\text { skośny }\end{array}$ & 0,69 & platykurtyczny \\
\hline \multirow{4}{*}{ ڤn } & $5 \mathrm{~A}$ & 2,02 & $\begin{array}{l}\text { drobnoziarnisty } \\
\text { piasek }\end{array}$ & 0,85 & umiarkowane & $-0,03$ & symetryczny & 0,88 & platykurtyczny \\
\hline & $5 \mathrm{~B}$ & 1,24 & $\begin{array}{l}\text { średnioziarnisty } \\
\text { piasek }\end{array}$ & 1,54 & słabe & $-0,21$ & ujemnie skośny & 0,81 & platykurtyczny \\
\hline & $5 \mathrm{C}$ & 3,58 & $\begin{array}{l}\text { bardzo } \\
\text { drobnoziarnisty } \\
\text { piasek }\end{array}$ & 1,58 & słabe & 0,63 & $\begin{array}{l}\text { bardzo } \\
\text { dodatnio } \\
\text { skośny }\end{array}$ & 1,30 & leptokurtyczny \\
\hline & $5 \mathrm{D}$ & 4,46 & $\begin{array}{l}\text { bardzo gruboziarnisty } \\
\text { mułek }\end{array}$ & 1,90 & słabe & 0,25 & $\begin{array}{l}\text { dodatnio } \\
\text { skośny }\end{array}$ & 0,69 & platykurtyczny \\
\hline
\end{tabular}


Tylko jedna próbka (2A) cechuje się wysortowaniem umiarkowanym, typowym dla niewielkich zmian w prędkości przepływu (Racinowski i in. 2001).

Profil Paplin 3 (ryc. 1, 3c) odznacza się wartościami wysortowania (tab. 1, ryc. 9b) w przedziale od 0,86 do 1,88 (średnio 1,31), co wskazuje na słabe wysortowanie osadu (próbki 3B, 3C, 3E) i zmienną dynamikę środowiska (Kenig 2009). Dwie próbki osadów (3A, 3D) charakteryzują się wysortowaniem umiarkowanym.
Profil Paplin 4 (ryc. 1, 3d) cechuje się wartościami wysortowania (tab. 1, ryc. 9b) w przedziale od 1,39 do 1,90 (średnio 1,71). Wszystkie próbki z tego profilu są słabo wysortowanie, co wskazuje na zmienną dynamikę środowiska (Kenig 2009).

Profil Paplin 5 (ryc. 1, 3e) charakteryzuje się wartościami wysortowania (tab. 1, ryc. 9b) w przedziale od 0,85 do 1,90 (średnio 1,47). Trzy próbki (5B, 5C, 5D) $z$ tego profilu odznaczają się słabym wysortowaniem, a tylko jedna (5A) umiarkowanym. Może to

a

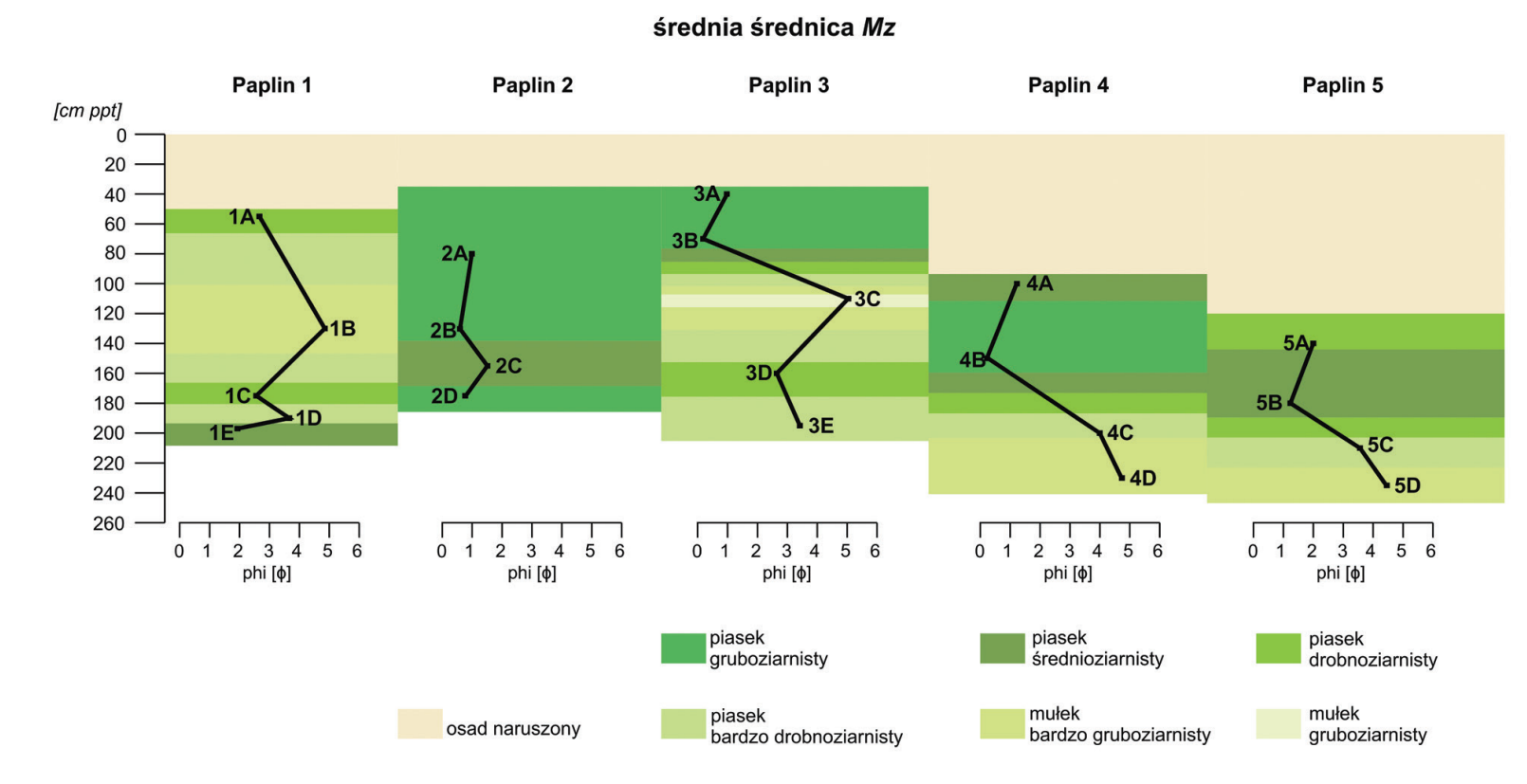

b

wysortowanie $\sigma 1$

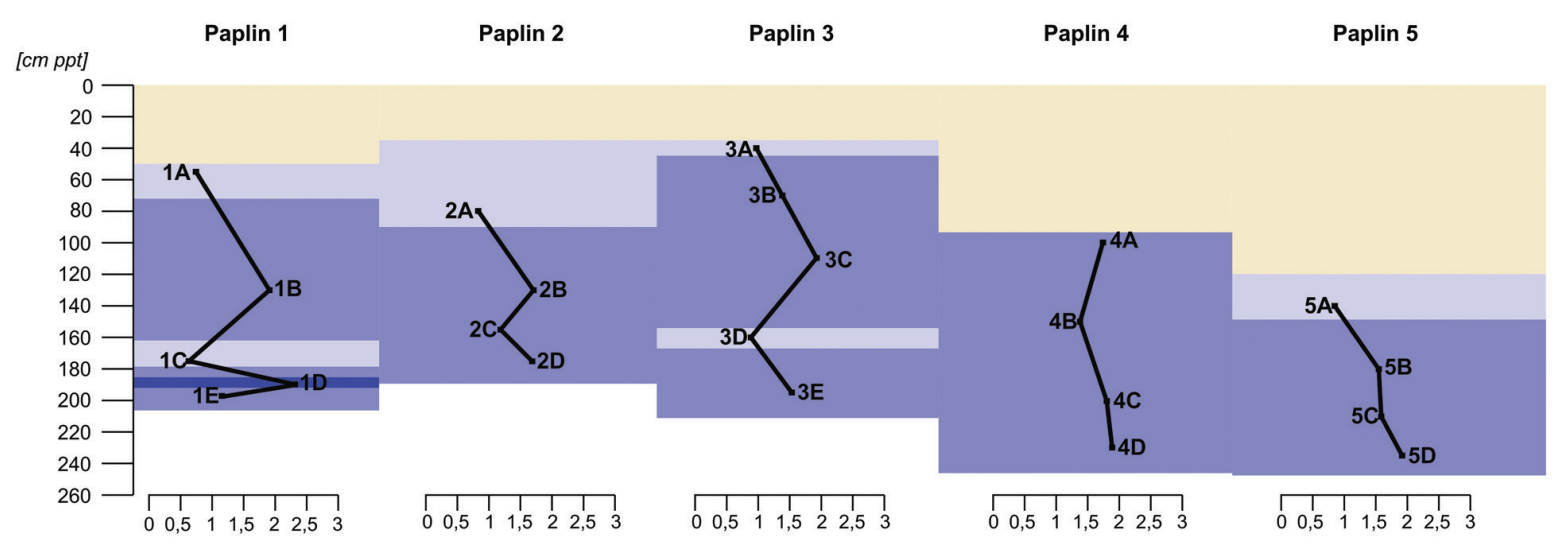

osad naruszony wysortowanie umiarkowane

wysortowanie słabe

Ryc. 9. Parametry uziarnienia

a) średnia średnica $\left(M_{z}\right)$, b) wysortowanie $\left(\sigma_{1}\right)$, punkty badawcze: profile Paplin - 1, 2, 3, 4 i 5

Fig. 9. Grain-size parameters

a) mean grain-size $\left(M_{z}\right)$, b) standard deviation $\left(\sigma_{1}\right)$, research points: profiles Paplin $-1,2,3,4$, and 5 
wskazywać na zmienną dynamikę środowiska (Racinowski i in. 2001).

W większości próbek $z$ analizowanych profili wysortowanie jest słabe, co jest typowe dla wielofrakcyjnych osadów, gdzie zmiennej dynamice środowiska odpowiada właśnie słabe wysortowanie (Kenig 2009).

\section{Skośność $\left(\mathrm{Sk}_{1}\right)$}

Wskaźnik ten informuje o zróżnicowaniu dynamiki prądowego środowiska sedymentacyjnego (Tucker 1988, Szmańda 2010).

W profilu Paplin 1 wartości skośności (tab. 1) wahają się w przedziale od $-0,39$ do 0,29 (średnio $-0,02)$. Ujemne wartości wskaźnika $S_{1}$ wskazują na wzbogacenie osadu we frakcje grubsze, co może być interpretowane jako przewaga prędkości większych od przeciętnych w danym środowisku. Może istnieć również tendencja do redepozycji materiału dennego (Racinowski i in. 2001).

Profile Paplin 2, 3, 4 i 5 charakteryzują się (średnia wartość) dodatnimi wartościami wskaźnika $S_{1}$ (tab. 1). Wartości te wynoszą w poszczególnych profilach: od $-0,12$ do 0,40 (średnio 0,08 ) dla profilu $\mathrm{Pa}-$ plin 2, od $-0,05$ do $1,28 \varphi$ (średnio $0,45 \varphi$ ) dla profilu Paplin 3, od 0,11 do 0,63 (średnio 0,42) dla profilu Paplin 4 oraz od $-0,21$ do 0,63 (średnio 0,16) dla profilu Paplin 5. Dodatnie wartości wskaźnika $S_{1}$ świadczą o doprowadzaniu frakcji drobnych i spadku prędkości przepływu (Tucker 1988, Racinowski i in. 2001). Następuje koniec transportu materiału poprzez saltację i początek wytrącania z zawiesiny (Visher 1969).

\section{Spłaszczenie $\left(\mathrm{K}_{\mathrm{G}}\right)$}

Wskaźnik spłaszczenia rozkładów uziarnienia informuje o stabilności dynamiki środowiska prądowego, jak również wskazuje na istnienie jednego, przeważającego, czy kilku źródeł materiału zasilającego dany obszar (Kenig 2009).

W profilu Paplin 1 wartość wskaźnika $K_{\mathrm{G}}$ (tab. 1) waha się od 0,73 do 1,65 (średnio 1,12). Średnia wartość spłaszczenia (oraz wartości dla próbek 1A, 1D) wskazuje na rozkład leptokurtyczny (spłaszczony), co może świadczyć o deficycie osadu $\mathrm{w}$ danym środowisku prądowym (Szmańda 2010). Jednak wartości tego wskaźnika różnią się w poszczególnych próbkach. Wartość spłaszczenia dla próbek 1B, 1E wskazuje na rozkład platykurtyczny (smukły), natomiast w przypadku próbki $1 \mathrm{C}$ rozkład jest mezokurtyczny (normalny). Takie zróżnicowanie wartości wskaźnika $\mathrm{K}_{\mathrm{G}}$ może świadczyć o zmiennej dynamice środowiska (Kenig 2009).

W profilu Paplin 2 wartość wskaźnika $\mathrm{K}_{\mathrm{G}}$ (tab. 1) waha się od 0,52 do 1,05 (średnio 0,76 ). Średnia wartość spłaszczenia (w tym wartości dla próbek 2B, 2D) wskazuje na rozkład platykurtyczny, co może świadczyć o obecności dużej ilości osadu w środowisku sedymentacyjnym (Racinowski i in. 2001). Wartości spłaszczenia dla próbek $2 \mathrm{~A}$ oraz $2 \mathrm{C}$ oznaczają rozkład mezokurtyczny.

W profilu Paplin 3 wartość wskaźnika $\mathrm{K}_{\mathrm{G}}$ (tab. 1) waha się od 0,66 do 2,06 (średnio 1,28). Średnia wartość spłaszczenia (w tym wartości dla próbek 3D, 3E) wskazuje na rozkład leptokurtyczny (spłaszczony), co może świadczyć o deficycie osadu $\mathrm{w}$ danym środowisku prądowym (Racinowski i in. 2001). Wartości spłaszczenia dla próbek 3B oraz 3C oznaczają rozkład platykurtyczny, natomiast wartości $\mathrm{K}_{\mathrm{G}}$ dla próbki $3 \mathrm{~A}$ - rozkład mezokurtyczny. Takie zróżnicowanie wartości wskaźnika $\mathrm{K}_{\mathrm{G}}$ może świadczyć o zmiennej dynamice środowiska (Kenig 2009).

W profilu Paplin 4 wartość wskaźnika $\mathrm{K}_{\mathrm{G}}$ (tab. 1) waha się od 0,47 do 1,13 (średnio 0,77). Średnia wartość spłaszczenia wskazuje na rozkład platykurtyczny, co może świadczyć o obecności dużej ilości osadu w środowisku (Tucker 1988). Jedynie dla próbki 4A wartości spłaszczenia oznaczają rozkład leptokurtyczny, co może wskazywać na czasowy brak dostawy materiału (Racinowski i in. 2001).

W profilu Paplin 5 wartość wskaźnika $\mathrm{K}_{\mathrm{G}}$ (tab. 1) waha się od 0,69 do 1,30 (średnio 0,92). Średnia wartość spłaszczenia, podobnie jak w przypadku profilu Paplin 4, wskazuje na rozkład platykurtyczny. Jedynie dla próbki 5C wartości spłaszczenia oznaczają rozkład leptokurtyczny.

\section{Obtoczenie i zmatowienie powierzchni ziaren kwarcowych}

Analizę obtoczenia i zmatowienia ziaren kwarcowych wykonano na frakcji piaszczystej $0,5-1,0 \mathrm{~mm}$. Ponieważ część próbek (1A, 1B, 4C, 5C, 5D) nie miała tej frakcji, nie mogły one zostać wykorzystane do badań.

Podczas analizy zmatowienia i obtoczenia wyróżniono siedem typów ziaren kwarcowych (Goździk 1995, Mycielska-Dowgiałło, Woronko 1998): NU nieobrobione, RM - okrągłe matowe, EL - obtoczone błyszczące, EM/RM - pośrednie matowe, EM/EL pośrednie błyszczące, $\mathrm{C}$ - pęknięte oraz inne.

Profil Paplin 1 charakteryzuje się przeważająca obecnością ziaren pośrednich matowych EM/RM $(33,7 \%)$ (ryc. 10a). Licznie występują również ziarna nieobrobione NU (24,5\%), okrągłe matowe RM $(20,2 \%)$ oraz pośrednie błyszczące EM/EL (17,9\%). Ziarna pęknięte C (1,9\%), obtoczone błyszczące EL $(1,6 \%)$ oraz inne $(0,2 \%)$ mają znikomy udział w badanych osadach. Taki charakter powierzchni ziaren kwarcowych może świadczyć o trwaniu procesów eolicznych na tym obszarze (Mycielska-Dowgiałło, Woronko 1998, Kenig 2009).

Podobnie jest w profilu Paplin 2, który charakteryzuje się przeważającą obecnością ziaren pośrednich matowych EM/RM (48,7\%) (ryc. 10b). Licznie wy- 
a

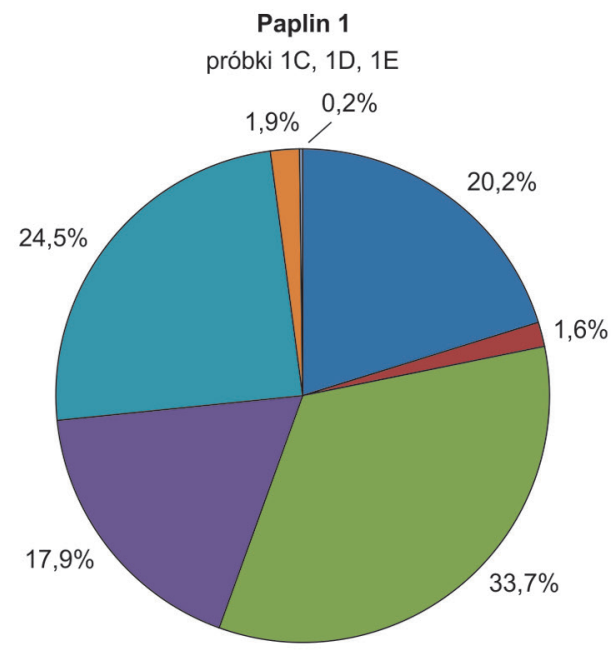

c

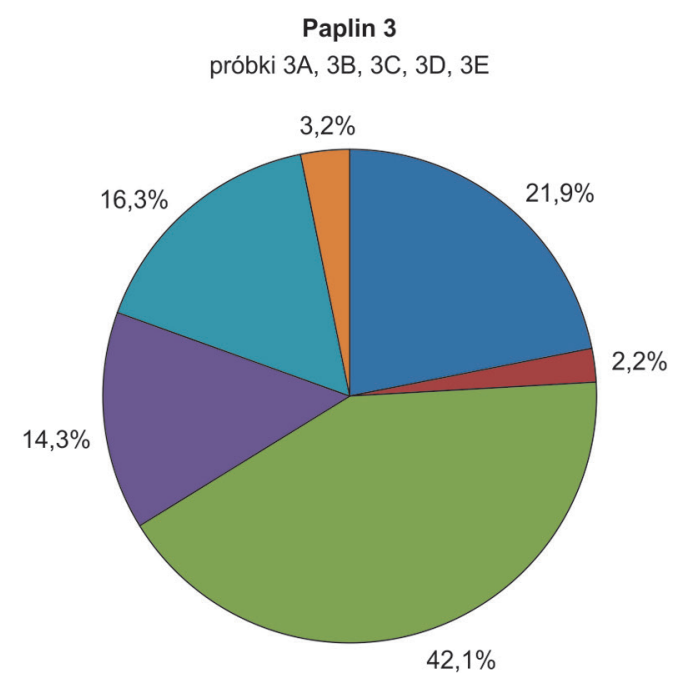

e

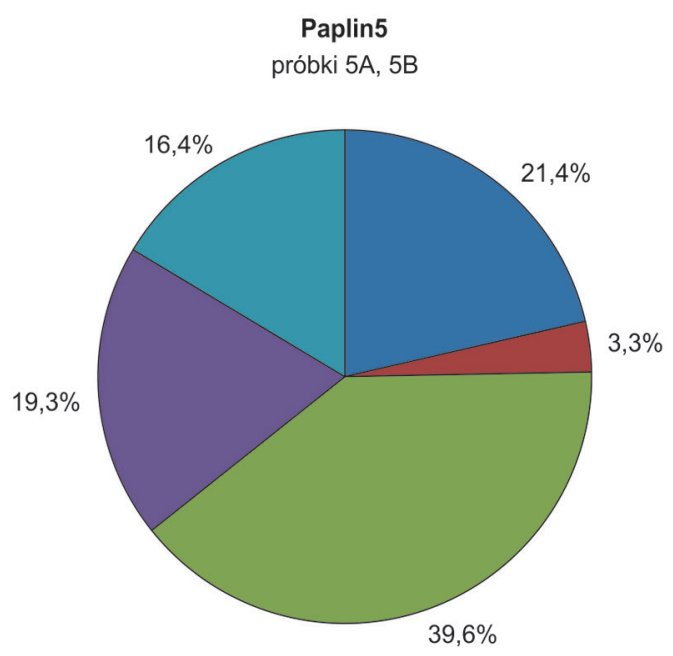

b

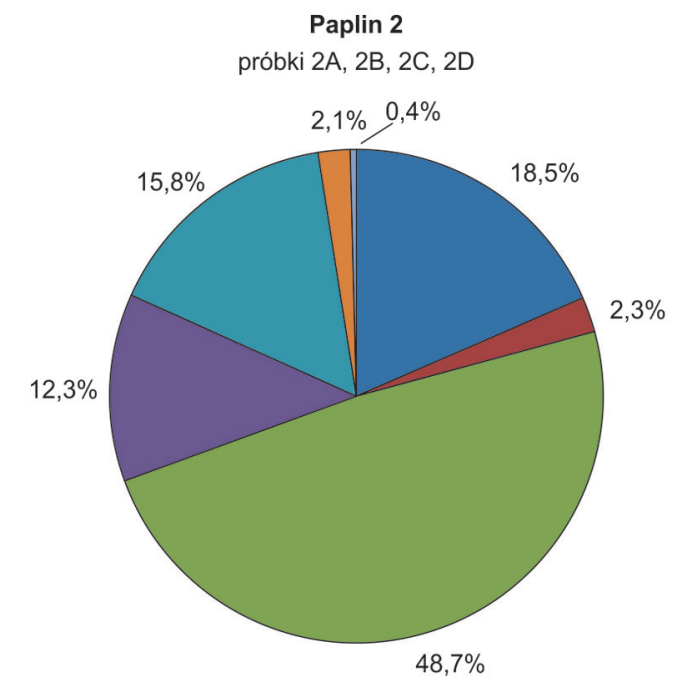

d

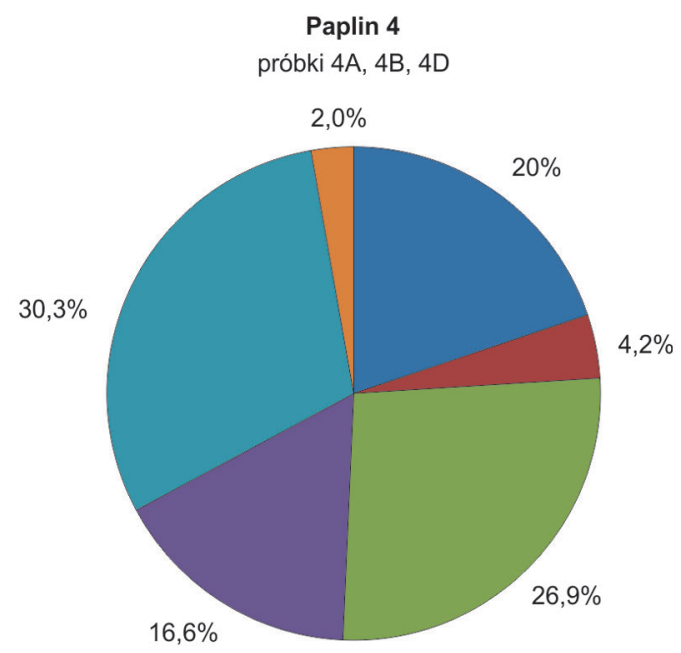

typy ziaren kwarcowych

$\square \mathrm{RM}$

$\square \mathrm{EL}$

$\square$ EM/RM

$\square \mathrm{EM} / \mathrm{EL}$

$\square \mathrm{NU}$

$\square \mathrm{C}$

$\square$ inne 


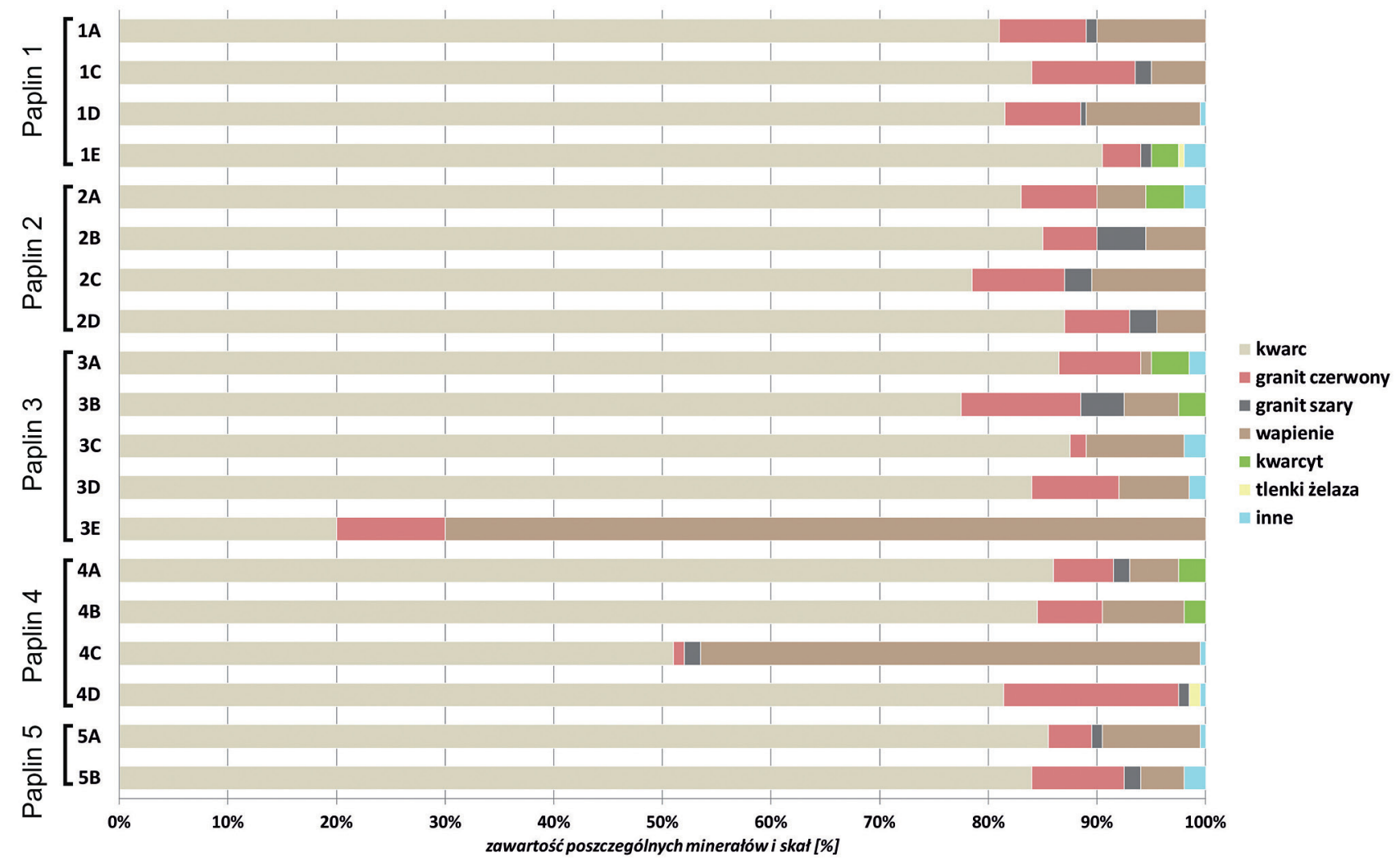

Ryc. 11. Skład mineralno-petrograficzny próbek ze żwirowni w Paplinie (profile Paplin 1, 2, 3, 4 i 5)

Fig. 11. The mineral-petrographic composition of samples from Paplin gravel pit (profiles Paplin 1, 2, 3, 4, and 5)

stępują również okrągłe matowe RM (18,5\%), ziarna nieobrobione NU $(15,8 \%)$ oraz pośrednie błyszczące EM/EL (12,3\%). Ziarna obtoczone błyszczące EL $(2,3 \%)$, pęknięte C $(2,1 \%)$ oraz inne $(0,4 \%)$ mają znikomy udział w badanych osadach.

Profil Paplin 3 cechuje się przeważającą obecnością ziaren pośrednich matowych EM/RM (42,1\%) (ryc. 10c). Licznie występują również ziarna okrągłe matowe RM (21,9\%), nieobrobione NU (16,3\%) oraz pośrednie błyszczące EM/EL (14,3\%). Ziarna pęknięte C $(3,2 \%)$ oraz obtoczone błyszczące EL $(2,2 \%)$ mają znikomy udział w badanych osadach.

W profilu Paplin 4 przeważają ziarna nieobrobione NU (30,3\%) (ryc. 10 d), jak również licznie występujące ziarna pośrednie matowe EM/RM (26,9\%). Ziarna okrągłe matowe RM oraz pośrednie błyszczące EM/EL stanowią odpowiednio $20 \%$ i $16,6 \%$ badanych ziaren. Ziarna obtoczone błyszczące EL (4,2\%) oraz pęknięte C (2\%) mają znikomy udział w badanych osadach.

W profilu Paplin 5 brak ziaren pękniętych $\mathrm{C}$ oraz innych (ryc. 10 e). Przeważają tutaj ziarna pośrednie matowe EM/RM (39,6\%). Licznie występują również ziarna okrągłe matowe RM (21,4\%), pośrednie błyszczące EM/EL (19,3\%) oraz nieobrobione NU $(16,4 \%)$. Ziarna obtoczone błyszczące EL (3,3\%) mają znikomy udział w badanych osadach. Taki charakter powierzchni ziaren kwarcowych może świad- czyć, podobnie jak w przypadku pozostałych profili, o transformacji osadów w środowisku eolicznym (Mycielska-Dowgiałło, Woronko 1998).

\section{Skład mineralno-petrograficzny}

W badanych osadach wyróżniono składniki mineralne (kwarc, tlenki żelaza) i składniki lityczne, czyli litoklasty (granit czerwony, granit szary, wapienie, kwarcyt), oraz grupę pojedynczych innych minerałów, nierozpoznanych pod mikroskopem. Część ziaren występowała w postaci zlepów węglanowo-kwarcowych.

We wszystkich próbkach, z wyjątkiem próbek 3E i 4C (ryc. 11), w składzie mineralogicznym dominują ziarna kwarcu. Ziarna kwarcu są bardzo odporne na proces wietrzenia fizycznego, a jego udział procentowy wzrasta $z$ czasem np. w miarę trwania procesu eolicznego. Kwarc może być transportowany na bardzo duże odległości, przez co jest bardzo dobrym wskaźnikiem tzw. dojrzałości mineralogicznej osadów, a wzrost jego udziału w osadzie następuje wskutek eliminacji składników mniej odpornych na wietrzenie fizyczne i chemiczne (Barczuk, Dłużewski 2006, Kenig 2009).

W badanych próbkach licznie występują również wapienie oraz granity czerwone, a granity szare, kwarcyty oraz tlenki żelaza - jedynie lokalnie. 


\section{Podsumowanie}

Podstawową frakcję (ryc. 4-8) w badanych osadach stanowi frakcja o średnicy $0,25-0,1 \mathrm{~mm}(41,7 \%)$ i średnicy poniżej $0,1 \mathrm{~mm}(21,3 \%)$. Z pozostałych frakcji na uwagę zasługuje ziarno o średnicy 1,0-0,5 $\mathrm{mm}(13,9 \%)$ oraz $0,5-0,25 \mathrm{~mm}$ (11\%). Ziarno grubsze, o średnicy $2,0-1,0 \mathrm{~mm}$ stanowi $4,6 \%$ badanego osadu. Natomiast frakcje drobnożwirowa $(4,0-2,0$ $\mathrm{mm})$ i średnio- i grubożwirowa $(>4,0 \mathrm{~mm})$ mają łączny 7,5-procentowy udział w budowie wysoczyzny polodowcowej. Jest to więc środowisko charakteryzujące się materiałem drobno- i bardzo drobnoziarnistym, o średnio zróżnicowanym składzie, co może wskazywać na niezbyt dynamiczne środowisko depozycji osadu.

Średnia wartość mediany (średniej średnicy) $\mathrm{Mz}$ we wszystkich badanych próbkach wynosi $2,42 \varphi$, co oznacza, że dominującym typem osadu na terenie żwirowni jest piasek drobnoziarnisty deponowany przede wszystkim z zawiesiny. Dodatnia średnia wartość dla całej żwirowni w Paplinie wskaźnika $\sigma_{1}(1,43$ 甲) oznacza dużą dynamikę środowiska oraz występowanie strefy rozmywania osadu. Dodatnie wartości wskaźnika $\mathrm{Sk}_{1}$ (średnio dla całej żwirowni $0,22 \varphi$ ) świadczą o doprowadzaniu frakcji drobnych i spadku prędkości przepływu (Racinowski i in. 2001, Kenig 2009, Szmańda 2010). W końcowym etapie transportu materiał jest przenoszony poprzez saltację, po czym następuje jego wytrącanie $z$ zawiesiny. Jeśli chodzi o wartość spłaszczenia, to profile Paplin 2, 4 i 5 charakteryzują się rozkładem platykurtycznym (spłaszczonym), co może świadczyć o dużym nasyceniu środowiska sedymentacyjnego osadem i depozycji osadu z zawiesiny. Natomiast profile Paplin 1 i 3 charakteryzują się rozkładem leptokurtycznym (smukłym), co wskazuje na deficyt osadu w środowisku.

Podczas analizy zmatowienia i obtoczenia (ryc. 10) wyróżniono siedem typów ziaren kwarcowych (Goździk 1995, Mycielska-Dowgiałło, Woronko 1998): NU - nieobrobione, RM - okrągłe matowe, EL - obtoczone błyszczące, EM/RM - pośrednie matowe, EM/ EL - pośrednie błyszczące, C - pęknięte oraz inne. W osadach wysoczyzny polodowcowej zaobserwowano wyraźną dominację ziaren matowych pośrednich, słabo obtoczonych EM/RM (38\%) nad ziarnami nieobrobionymi NU (21\%) i matowymi okrągłymi (RM (20,3\%). Ziarna błyszczące pośrednie EM/EL stanowiły $15,9 \%$ badanych ziaren, natomiast ziarna błyszczące zaokrąglone EL - 2,7\%. Stwierdzono równocześnie obecność jedynie $2 \%$ typowych ziaren pękniętych C, które mogły uzyskać swój kształt w środowisku glacjalnym na skutek istniejących $\mathrm{w}$ nim silnych napięć ścinających (w osadach południowo-wschodniej ściany wyrobiska widoczne są zaburzenia glacitektoniczne osadów) oraz podczas transportu glacjalnego.
Dominacja ziaren typu EM/RM może wskazywać na wzrost aktywności procesów eolicznych $\mathrm{w}$ czasie akumulacji badanych osadów (Mycielska-Dowgiałło, Woronko 1998, Kenig 2009).

W analizowanych próbkach (ryc. 11) dominują ziarna kwarcu (78,9\% wszystkich badanych ziaren). Okruchy wapieni i fragmenty czerwonego granitu stanowią odpowiednio $11,2 \%$ i $7 \%$ badanych ziaren. W badanych próbkach znaleźć można również szare granity $(1,3 \%)$ oraz kwarcyty $(0,9 \%)$. Pozostałe ziarna mineralne stanowią mniej niż $1 \%$ ziaren poddanych analizie mineralogicznej.

Wyniki badań terenowych i laboratoryjnych wskazują na duże zróżnicowanie badanych osadów: od dominujących osadów drobnoziarnistych deponowanych $\mathrm{w}$ niskoenergetycznym środowisku, charakteryzujących się warstwowaniami przekątnymi i rynnowymi, do osadów gruboziarnistych deponowanych $\mathrm{w}$ środowisku intensywnego przepływu wód $\mathrm{z}$ topniejącego lądolodu. Większość osadów była transportowana $\mathrm{w}$ zawiesinie.

\section{Podziękowania}

Autorki dziękują dr. inż. Bogusławowi Marcinkowskiemu z Państwowego Instytutu Geologicznego PIB za wykonanie analiz składu mineralno-petrograficznego badanych osadów.

\section{Literatura}

Allen G.P., Castaing P., Klingebiel A., 1972. Distinction of elementary sand populations in the Gironde Estuary (France) by r-mode factor analysis of grain-size data. Sedimentology 19: 21-35.

Barczuk A., Dłużewski M., 2006. Skład mineralno-litologiczny jako podstawa do określenia źródła i wskaźnik stopnia eolizacji osadów wydmowych. W: M. Dłużewski, I. Tsermegas (red.), Przewodnik terenowy: Geograficzne i geologiczne uwarunkowania rozwoju rzeźby Maroka. Warsztaty Geomorfologiczne Maroko 2006. Wydział Geografii i Studiów Regionalnych Uniwersytet Warszawski oraz Stowarzyszenie Geomorfologów Polskich: 103-112.

Folk R.L., Ward W.C., 1957. Brazos River bar: a study in the significance of grain size parameters. Journal of Sedimentary Petrology 27: 3-26.

Glińska A., Pytliński S., Bębenek S., Kicińska A., Strzeboński P., 2006. Karta Ewidencyjna Stanowiska Dokumentacyjnego „Osady glacjalne w żwirowni w Paplinie” nr LDZ 0708 01, PIG-CAG.

Glińska A., Pytliński S., Bębenek S., Kicińska A., Strzeboński P., 2010. Karta Dokumentacyjna Geostanowiska „Żwirownia w Paplinie - osady polodowcowe" nr 1449. Ministerstwo Środowiska, PIG-CAG.

Goździk J., 1980. Zastosowanie morfometrii i graniformetrii do badań osadów w kopalni węgla brunatnego Bełchatów. Stud. Region., 4.

Goździk J., 1995. Wybrane metody analizy kształtu ziarn piasków dla celów paleogeograficznych i stratygraficznych. W: E. Mycielska-Dowgiałło, J. Rutkowski (red.), Badania osadów czwartorzędowych. Wybrane metody i interpretacja wyników: 115-132.

Janicki T., 2007. Dodatek nr 1 do dokumentacji geologicznej złoża kruszywa naturalnego „Paplin I” w kat. C1 rozliczający zasoby 
złoża. Zakład Usług Geologicznych i Ochrony Środowiska; PIG-CAG.

Kenig K., 1999. Analiza składu mineralno-petrograficznego frakcji piaszczystej. W: L. Marks, A. Ber (red.), Metodyka opracowania Szczegółowej mapy geologicznej Polski w skali 1:50 000. Wydawnictwa Państwowego Instytutu Geologicznego.

Kenig K., 2009. Litologia glin morenowych na Niżu Polskim - podstawowe metody badawcze. Biuletyn Państwowego Instytutu Geologicznego 437: 1-58.

Krumbein W.C., 1941. Measurement and geological significance of shape and roundness of sedimentary particles. Journal of Sedimentary Petrology 11: 54-72.

Markowiak M., 2010. Karta Dokumentacyjna Geostanowiska „Żwirownia w Paplinie” nr 1617. Ministerstwo Środowiska, PIG-CAG.

Mycielska-Dowgiałło E., 1995. Wybrane cechy teksturalne osadów i ich wartość interpretacyjna. W: E. Mycielska-Dowgiałło, J. Rutkowski (red.), Badania osadów czwartorzędowych. Wybrane metody i interpretacja wyników: 29-104.

Mycielska-Dowgiałło E., 2001. Eolizacja osadów jako wskaźnik stratygraficzny czwartorzędu. Pracownia Sedymentologiczna, Wydział Geografii i Studiów Regionalnych, Uniwersytet Warszawski, Warszawa.
Mycielska-Dowgiałło E., 2007. Metody badań cech teksturalnych osadów klastycznych i wartość interpretacyjna wyników. W: E. Mycielska-Dowgiałło, J. Rutkowski (red.), Badania cech teksturalnych osadów czwartorzędowych i wybrane metody oznaczania ich wieku. Wydawnictwo SWPR, Warszawa: 95-180.

Mycielska-Dowgiałło E., Woronko B., 1998. Analiza obtoczenia i zmatowienia powierzchni ziarn kwarcowych frakcji piaszczystej i jej wartość interpretacyjna. Przegląd Geologiczny 46: 1275-1281.

Mycielska-Dowgiałło E., Ludwikowska-Kędzia M., 2011. Alternative interpretation of grain-size data from Quaternary deposits. Geologos 17(4): 189-203.

Racinowski R., Szczypek T., Wach T., 2001. Prezentacja i interpretacja wyników badań uziarnienia osadów czwartorzędowych. Wydawnictwo Uniwersytetu Śląskiego, Katowice.

Szmańda J.B., 2010. Litodynamiczna interpretacja środowiska fluwialnego na podstawie wskaźników uziarnienia - przegląd wybranych metod. Landform Analysis 12: 109-125.

Tucker M. (red.), 1988. Techniques in Sedimentology. Blackwell Scientific Publications.

Visher G.S., 1969. Grain-size distributions and depositional processes. Journal of Sedimentary Petrology 39: 1074-1106. 